\title{
化工澱粉糊化粒子の膨潤に及ぼすずり応力の影響
}

\author{
朝田 仁 ${ }^{\S}$ ，鈴木寛一* \\ ヤマキ株式会社 \\ $*$ 広島大学大学院生物圈科学研究科
}

\section{Effect of Cross-linking Levels and Starch Concentration on Shear-dependent Flow Properties of Gelatinized Modified Starch Suspension}

\author{
Hitoshi Asada ${ }^{\S}$ and Kanichi Suzuki* \\ Yamaki Co., Ltd., 1698-6 Kominato, Iyo, Ehime 799-3194 \\ * Graduate School of Biosphere Science, Hiroshima University, \\ 1-4-4 Kagamiyama, Higashihiroshima 739-8528
}

\begin{abstract}
Cross-linked starch suspensions sheared at various shear stresses showed two types of flow behavior. One type indicates a behavior of increasing fluidity, which is observed in concentrated suspensions of weakly cross-linked starch. Although sheared granules are smaller than non-sheared granules, the increasing fluidity of cross-linked starch suspensions is explained by the rupture of fully swollen starch granules. As the swollen granules rupture, the flocculation network of the granules decreases, resulting in a decrease in the viscosity and an increase in the fluidity of starch suspensions. Another flow behavior is decreasing fluidity, which is observed in highly cross-linked starch. The decreasing fluidity of cross-linked starch suspensions results from the re-swelling of granules from the application of unheated shear stress. The re-swollen granules enlarge with strong flocculation, resulting in a decrease of fluidity. Hence, the disruption or the re-swelling of sheared granules explains the two types of fluidity observed in cross-linked starch suspensions. A combination of cross-linking level and starch concentration determines the fluidity type of gelatinized suspensions.

(Received Nov. 1, 2006 ; Accepted Feb. 28, 2007)
\end{abstract}

Keywords : modified starch, gelatinization, shear stress, fluidity, rheology キーワード : 化工澱粉, 膨潤, ずり応力, 流動性, 食品レオロジー

中・高粘度のたれ類は, 食品素材に浸透させて調味する 低粘度のたれ類よりあ，そのレオロジー特性は非常に重要 な因子となる。また，このたれ類のレオロジー特性は，そ の増粘剤として用いられる化工澱粉自身の糊化・膨潤, レ オロジー特性に大きく影響を受ける.

前報 ${ }^{12)}$ では, 化工澱粉の由来澱粉種や変性処理が，化工 澱粉糊化液の流動パラメータに与える影響について検討し た。 そして，その化工澱粉の中で，負荷されたずり応力に 対して全く逆の 2 種類の流動挙動があることを確認し, そ のずり応力と流動挙動の関係を検討した.これら 2 種類の 流動挙動は, ワキシーコーンスターチ由来のヒドロキシプ ロピルリン酸架橋澱粉で認められた負荷したずり応力に依 存して流動性が低下するタイプ (shear thickening flow) と, 逆に, バレイショ由来のヒドロキシプロピルリン酸架

干799-3194 伊予市米湊 1698-6

* =739-8528 東広島市鏡山 1 丁目 4-4

$\S$ 連絡先 (Corresponding author), hasada@yamaki.co.jp
橋澱粉で確認された流動性が増加するタイプ (shear thining flow）であった ${ }^{3)}$.

たれ類の生産現場では，バッチ式のニーダーで原材料を ブレンドし，加熱・攪拌によって増粘剤の化工澱粉を糊 化・膨潤させており，糊化終了直後に，たれ類の粘度や流 動性の品質を管理している。なぜなら，品質管理時のたれ が粘度不足である場合は，そのまま再加熱したり，一定温 度で保持したりして粘度発現を促せるためである。その 後, 品質管理值に適合したたれ類はニーダーからポンプに よってパイプ・チューブを通り充填機へと輸送されるが, 化工澱粉で増粘されたたれは，この輸送中にさらにずり応 力を受けていることになる，このことは，品質管理值と容 器充填後のたれの物性值は，その途中工程で負荷されるず り応力によって, 值が異なるという大きな問題をはらむこ とになる。そこで, この物性值 (流動挙動) の变化の原因 を, 増粘剤である化工澱粉の糊化とずり応力負荷に伴う澱 粉粒子の膨潤の面から検討した。 
澱粉の膨潤状態を評価するための粒子径や粒度分布は, コーンスターチ ${ }^{4)}$ やササゲ澱粉5) において加熱温度や加熱 時間との関係 ${ }^{6)}$ で測定され，さらにコーンスターチや架橋 澱粉の糊化との関係 ${ }^{7)}$ でも研究されているが, 流動挙動や ずり応力との関係については研究されていない. そこで本 研究では, 化工澱粉の糊化液に与えるずり応力を変化させ た時の澱粉糊化粒子の状態を調べ, 流動挙動の变化の原因 を港粉の膨潤から検討した。

\section{実 験 方 法}

\section{1. 供試澱粉および試料の調製}

リン酸架橋型の化工澱粉は, 架橋度の増加に従って糊化 時における澱粉粒子の膨潤が抑制される に用いた化工澱粉は, 置換基, 置換度がほぼ同じでリン酸 架橋度だけが異なり, たれ類の増粘剤として汎用されてい る市販のヒドロキシプロピルリン酸架橋澱粉を用いた. こ の化工澱粉は, 便宜的に以下のように呼称し, 变性内容を 示した。

(1) WHP-1：ワキシーコーンスターチのヒドロキシプ ロピルリン酸架橋港粉（低架橋度，置換度 $4.0 \%$ )

(2) WHP-2: ワキシーコーンスターチのヒドロキシプ ロピルリン酸架橋澱粉（中架橋度，置換度 $4.3 \%$ )

(3) WHP-3 : ワキシーコーンスターチのヒドロキシプ ロピルリン酸架橋澱粉（高架橋度, 置換度 $4.3 \%$ )

WHP-1，-2，-3 については日本コーンスターチ(株)より 市販品を入手した.

これらの糊化液の調製は前報1) と同様に行った。即ち, 蒸留水に各化工澱粉を加えた懸濁液 $2000 \mathrm{~g}$ を $92^{\circ} \mathrm{C}$ まで加 熱, 糊化させた後, $20^{\circ} \mathrm{C}$ まで急冷し, 試料とした。加熱の 昇温速度は約 $6^{\circ} \mathrm{C} / \mathrm{min}$, 冷却の降温速度は約 $7^{\circ} \mathrm{C} / \mathrm{min}$ で, この条件は全ての試料について同一とした。

\section{2. ヒステリシスループ}

それぞれ，3.0，4.0，5.0 wt\% に調製した各化工澱粉糊化 液の流動特性を，前報122) で用いたのと同じ反復測定が可 能な管形粘度計を使用し測定した。流動特性の解析も前 報1)2）之同様に行った。即ち, 流動方程式は, 時間依存性の ない非ニュートン流体に対する Herschel-Bulkley 式' で 解析した。

$$
\mathrm{d} \gamma / \mathrm{d} t=1 / K\left(\tau-\tau_{\mathrm{y}}\right)^{n}
$$

ここで, $\mathrm{d} \gamma / \mathrm{d} t$ : ずり速度 $\left(\mathrm{s}^{-1}\right), \tau$ : ずり応力 $(\mathrm{Pa}), \tau_{\mathrm{y}}$ : 降伏值 $(\mathrm{Pa}), K$ : コンシステンシー係数 $\left(\mathrm{Pa}^{\mathrm{n}} \cdot \mathrm{s}\right), n$ : 流動 挙動指数（一)，流体が円管内を流れる場合には，式(1)は 次式となる ${ }^{10)}$.

$$
Q=\left\{\pi r_{\mathrm{w}}^{3}\left(\tau_{\mathrm{w}}-\tau_{\mathrm{y}}\right)^{n}\right\} /\{K(3+N)\}
$$

ここで, $Q$ : 体積流速 $\left(\mathrm{m}^{3} / \mathrm{s}\right), r_{\mathrm{w}}$ : 円管の半径 $(\mathrm{m}), \tau_{\mathrm{w}}$ : 管壁でのずり応力 $(\mathrm{Pa})$.

$$
N=\mathrm{d} \ln \left(4 Q / \pi r_{\mathrm{w}}^{3}\right) / \mathrm{d} \ln \tau_{\mathrm{w}}
$$

で求められる值である.

流動パラメータ $K, n, \tau_{\mathrm{y}}$ の值は式 (2)を用いて, 流速 $Q$ と 管壁でのずり応力 $\tau_{\mathrm{w}}$ との関係より求めた.

本研究に用いた 3 種類の化工澱粉糊化液を, 前報 ${ }^{122)}$ で 用いた管形粘度計の測定ずり応力を上昇, 下降させて各糊 化液の流動曲線を測定し，そのヒステリシスループの形を 調べた。この時の各化工港粉糊化液の濃度は，たれの増粘 剤として添加される $3.0 \sim 5.0 \%(\mathrm{w} / \mathrm{w})$ で行った.この得 られたヒステリシスループによって，各糊化液に設定した ずり応力を負荷した時に，どのように流動挙動が変化する かを把握した。ささに，描かれた各化工澱粉の各濃度での ヒステリシスループから，負荷したずり応力によって流動 性が増加する場合と低下する場合の澱粉の種類と濃度の組 合せを選んだ。

\section{3. ずり応力の負荷}

各化工澱粉のそれぞれの濃度で描かれたヒステリシス ループの形から，ずり応力の負荷によって流動性が増加す る場合と低下する場合の代表的な化工澱粉の種類と濃度の 組合せを選んだ. 即ち，ずり応力の負荷によって流動性が 増加する組合せとして $4.5(\mathrm{w} / \mathrm{w})$ WHP-1 糊化液を, また, 流動性が低下する組合せとして 4.5\% (w/w) WHP-2 糊化 液と $5.0 \%(\mathrm{w} / \mathrm{w})$ WHP-3 糊化液を選択した.

前報 ${ }^{1)}$ で用いた管形粘度計を用いて，上記の糊化液にそ れぞれ設定したずり応力を負荷した時のみかけ粘度と糊化 澱粉粒子の平均粒径を測定した。負荷したずり応力は，先 のヒステリシスループ測定を行った時の体積流速とずり応 力值を参考にして澱粉糊化液ごとに設定した。ずり応力の 負荷方法は, 前報 ${ }^{3)}$ と同様に行った. 即ち, 本実験で用いた 管形粘度計は，試料を 2 つのシリンダーの間を反復流動さ せることで連続して測定でき，体積流速 $Q$ は，試料を 100 $\mathrm{ml}$ 流動させた流動時間を測定して求めたが，この測定を 同一圧力で 5 往復, 即ち 10 回行い, その測定值の平均值を 求めた。これを流速測定の 1 セットとした。この 1 セット の流速測定（5 往復）には約 100〜250 秒を要したことか ら，1セットの測定にはずり応力が約 100〜250 秒間負荷さ れていることになる.

こうして, 4.5\% (w/w) WHP-1 糊化液では，管形粘度計 での初発一定ずり応力を $213 \mathrm{~Pa}$ に設定して, 体積流速を 1 セット（10回）測定し, 次いであらかじめ設定したずり応 力として 213，312，402，480，527 Pa でその体積流速を各 2 セット測定し，その後再び，元の $213 \mathrm{~Pa}$ に戻して体積流 速を 1 セット測定した. $4.5 \%$ （w/w）WHP-2 糊化液の場 合は, $215 \mathrm{~Pa}$ の一定ずり応力で体積流速を 1 セット測定, 次いで，それぞれ 215，320，414，482，544 Pa の各高ずり 応力でその体積流速を 2 セット測定, その後再び, $215 \mathrm{~Pa}$ に戻して体積流速を測定した。 $5.0 \%$ （w/w）WHP-3 糊化 


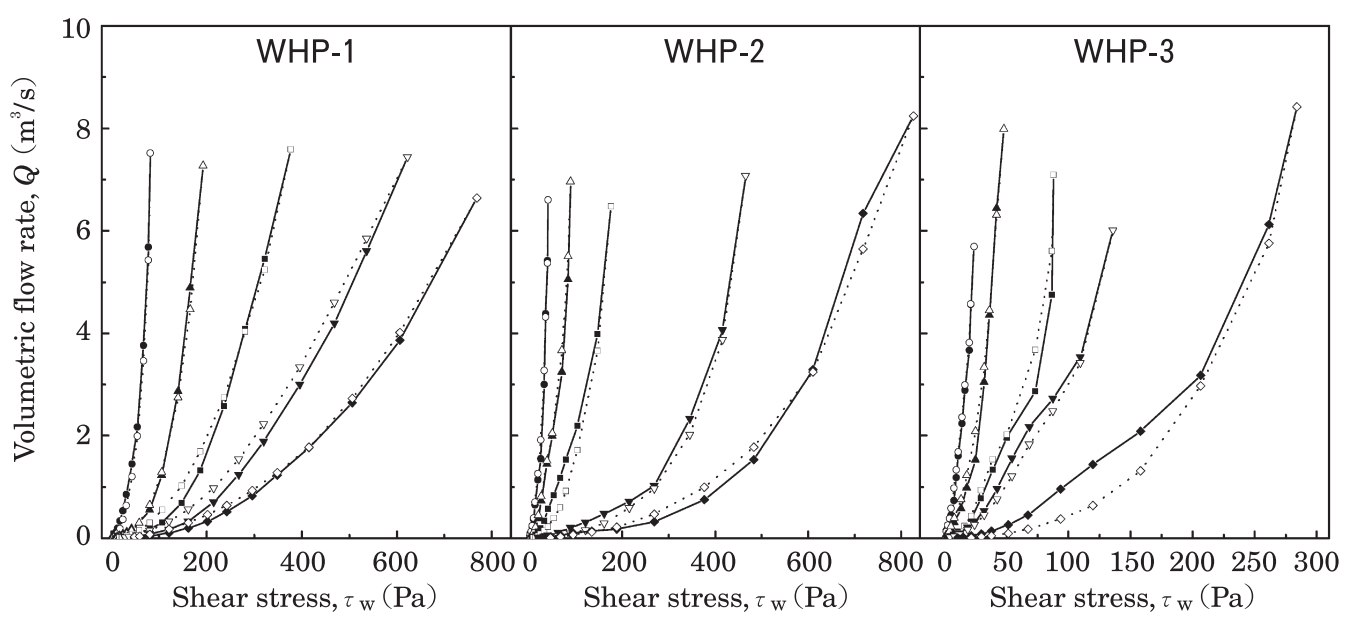

Fig. 1 Flow hysteresis loops of gelatinized starch suspensions at different concentrations

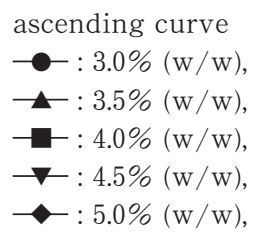

液は, $105 \mathrm{~Pa}$ の一定ずり応力で体積流速を 1 セット測定, 次いで，それぞれ 105，178，244，280，350 Pa の各高ずり 応力でその体積流速を 2 セッ卜測定, その後再び, $105 \mathrm{~Pa}$ に戻して体積流速を測定した。これら糊化液は, 高ずり応 力を負荷する前後でサンプリングし，それぞれのみかけ粘 度之糊化澱粉粒子の平均粒子径を測定した。このずり応力 負荷は, 全て $20 \pm 0.2^{\circ} \mathrm{C}$ で行った。

\section{4. みかけ粘度の測定方法}

みかけ粘度 $\mu_{a}$ は, コーンプレート形の $\mathrm{E}$ 形粘度計 (東機 産業(株)：EHD 型）を用いて測定した。即ち, 粘度計の コーンは, $\phi 48 \mathrm{~mm}, 1^{\circ} 34^{\prime \prime}$ を用い, 化工港粉糊化液を, $20 \pm$ $0.2^{\circ} \mathrm{C}$ の温度で, 回転数 $20 \mathrm{rpm}$ で 7 分間測定した時の值を みかけ粘度 $\mu_{a}$ とした。

\section{5. 糊化澱粉粒子径および粒度分布の測定方法}

糊化澱粉粒子の平均粒子径掞よび粒度分布は, 光散乱回 折タイプ粒度分布測定装置（(株)コールター製, LS 200 型）を用いて測定した。測定条件は蒸留水を分散媒とし, 分散屈折率 1.322 , サンプル屈折率 1.6 を用い, 得られた粒 度分布を(株)コールター製のソフトウェアで解析して, 平 均粒子径 $(\mu \mathrm{m})$ を算出した。この平均粒子径は, 5 回の測 定值を平均した。

\section{実験結果および考察}

\section{1. ヒステリシスループ}

各 3.0 5.0\%（w/w）糊化液において得られた流動七ス テリシスループを Fig. 1 に示す. WHP-1，-2，-3 のすべて の糊化液で降伏值を持たない擬塑性流体的な挙動を示し た。この Fig. 1 で描かれた流動曲線は, 各澱粉糊化液にお descending curve

$\cdots \circ \cdots: 3.0 \%(\mathrm{w} / \mathrm{w})$,

$\triangle \cdots: 3.5 \%(\mathrm{w} / \mathrm{w})$,

$\cdots \square: 4.0 \%(\mathrm{w} / \mathrm{w})$,

$\cdots \nabla \cdots: 4.5 \%(\mathrm{w} / \mathrm{w})$,

$\cdots \diamond \cdots: 5.0 \%(\mathrm{w} / \mathrm{w})$
ける最大ずり応力範囲が異なるために，上昇曲線と下降曲 線で描かれるヒステリシスループの形状が判別しにくい が，本研究で使用した管形粘度計の測定においては，再現 性のあるデー夕として描かれたものであり, 大きく 3 の夕 イプに分けることができた. 即ち, このヒステリシスルー プは，それぞれ上昇曲線が下降曲線を上回る挙動（shear thickening flow), 逆に下降曲線が上昇曲線を上回る挙動 (shear thining flow) あるいは, 両挙動の混合形の 3 つの タイプの流動ヒステリシスを持つことを認めた。具体的に は, WHP-1 の 4.5, $5.0 \%(\mathrm{w} / \mathrm{w})$ と WHP-2 の 3.5\% (w/ $\mathrm{w} ）$ と WHP-3 の 3.0, 3.5, $4.0 \%(\mathrm{w} / \mathrm{w})$ 糊化液ではチキy トロピー的挙動を示し, WHP-2 の 4.0, $4.5 \%(\mathrm{w} / \mathrm{w})$ と WHP-3 の 4.5, 5.0\% ( w/w) 糊化液では上昇曲線が下降曲 線を上回る挙動を，その他の澱粉糊化液では混合形挙動を 示した。これらの流動ヒステリシスは, どの流動とも静置 後に回復しなかった。

この化工澱粉の種類と濃度によって流動挙動が異なる原 因は, 檜作の報告 ${ }^{11}$ を基に, 測粉の糊化状態（膨潤状態・ 粒子径) と濃度（糊化液密度）の違いの組合せによると推 定した。 さらに，糊化直後の各糊化粒子を顕微鏡観察する と，すべての糊化液で膨潤した糊化澱粉粒子が確認でき た. 即ち, すべての澱粉糊化液は, リン酸架橋により糊化 しても粒が崩壊せずに水和・膨潤したまま残っていること を示している，そのため，これらの流動挙動の違いは，膨 潤澱粉粒子内に取り込まれた水の量之連続相の水量の比率 とその粒子数によって起こると仮定した．この水量の比率 の違いは, リン酸架橋度による測粉自身の膨潤力の差や澱 粉濃度（総澱粉粒子数）に大きく関与しており, これらの組 
合せによって 3 つの流動挙動のタイプが決定すると考えた.

\section{2. ずり応力負荷の影響}

(1) 流動性が増加する場合

ヒステリシスループで下降曲線が上昇曲線を上回る挙 動, 即ち, 流動性が増加する挙動を示した $4.5 \%(\mathrm{w} / \mathrm{w})$ WHP-1 糊化液に, 設定したずり応力を負荷した時のみか け粘度之糊化澱粉粒子径の変化を Fig. 2 に示す.

Fig. 2 より, 糊化液のみかけ粘度は, 負荷したずり応力 の増加に伴って $320 \mathrm{~Pa}$ までは増加したが， $320 \mathrm{~Pa}$ を超え ると急激に減少した。 さらに，この時の糊化澱粉粒子径の 挙動む同様であった。これは, 負荷したずり応力による澱 粉粒子径とみかけ粘度の挙動が密接に関係しているためと 推察した. また, 負荷ずり応力が $320 \mathrm{~Pa}$ を超えると, 糊化 澱粉粒子径は小さくなることで, みかけ粘度が減少したこ

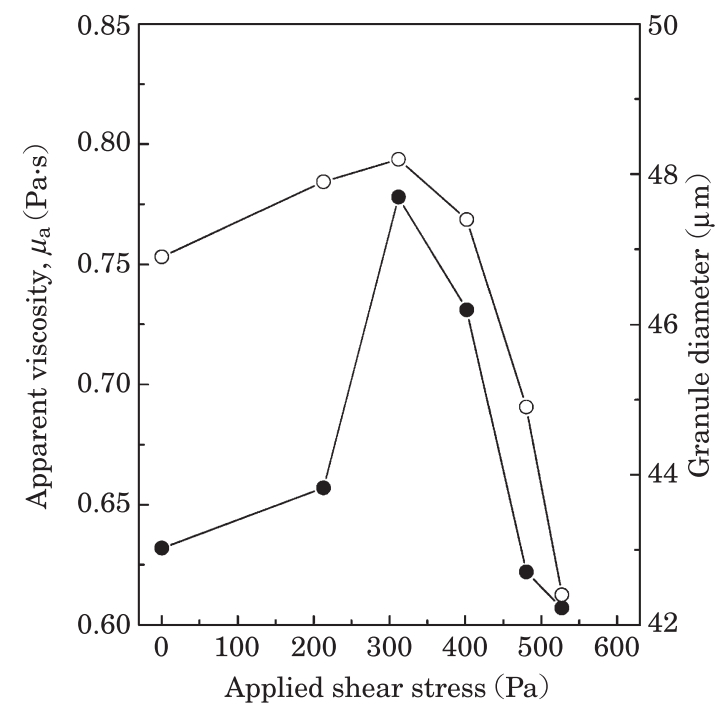

Fig. 2 Influence of applied shear stress on apparent viscosity and granule diameter of $4.5 \%(\mathrm{w} / \mathrm{w})$ WHP-1 suspensions

Measurement temperature ; $20^{\circ} \mathrm{C}$

- - : apparent viscosity

$-\bigcirc$ : granule diameter
とを示している.この負荷ずり応力が $320 \mathrm{~Pa}$ を超えた時 の澱粉粒子径の挙動に着目して, みかけ粘度の減少と, 糊 化液の流動性増加について検討を加えた。

この糊化澱粉粒子径の変化をより詳細に表すために，各 ずり応力負荷後の糊化液の粒度分布を Fig. 3 に，その時の 糊化粒子の顕微鏡写真を Fig. 4 に示す. Fig. 3 では全ての 分布曲線は単一のピークを示した. $312 \mathrm{~Pa}$ 負荷での分布曲 線は, 未ずりの曲線に比べて大粒径側へシフトし, 糊化澱 粉粒子が全体的に増大（膨潤）していることを示した。逆 に $527 \mathrm{~Pa}$ を負荷すると，分布曲線は大きく小粒径側へ変 化した. $45 \mu \mathrm{m}$ でのピークが小さくなるとともに，約 $22 \mu$ $\mathrm{m}$ に粒度分布曲線の小さなピークが表れた。この小さな ピークは，崩壊した澱粉粒子の破片と推定され，澱粉粒子 が壊れていることを示している.

これら粒度分布の变化の状態を Fig. 4 の糊化粒子写真 で裏付けた。 即ち, $92^{\circ} \mathrm{C}$ 加熱直後の（a）では澱粉粒は水を 取り込んで大きく膨潤しているが，この膨潤港粉表面は㱀 が多く，十分に膨らみきっていない状態であった. $312 \mathrm{~Pa}$, $527 \mathrm{~Pa}$ の各ずり応力を負荷した直後の糊化粒子の状態が （b）（c）である．ずり応力を負荷すると（a）での膨潤粒子 の粒径がさらに大きく, 粒子表面の㗙の状態の变化む見ら

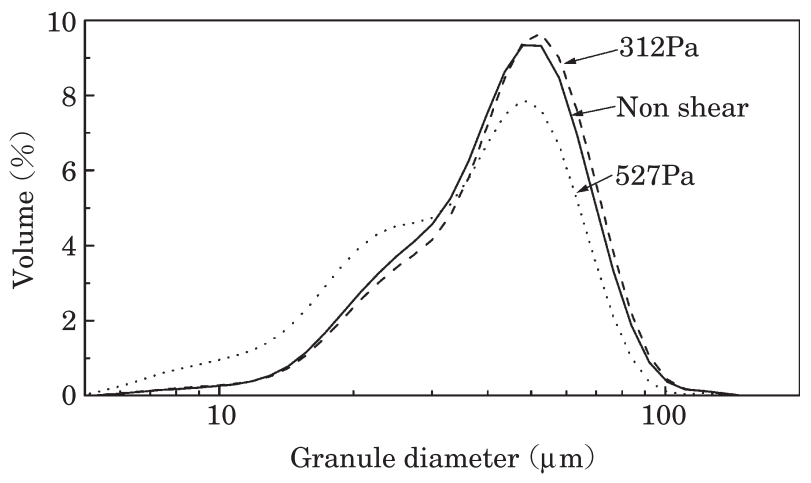

Fig. 3 Influence of applied shear stress on average granule size distribution of gelatinized $4.5 \%$ (w/w) WHP-1 suspensions
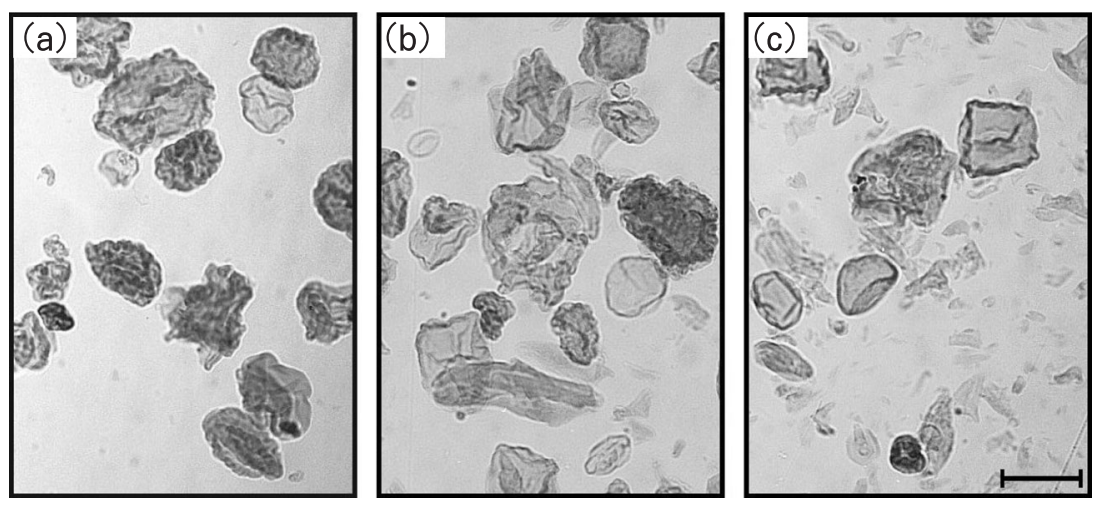

Fig. 4 Photomicrographs of gelatinized $4.5 \%(\mathrm{w} / \mathrm{w})$ WHP-1 granule (a) : Non shear, (b) : $312 \mathrm{~Pa},(\mathrm{c}): 527 \mathrm{~Pa}, \mathrm{bar}=50 \mu \mathrm{m}$ 
れ, 澱粉粒子がさらに膨潤している状態が観察された。こ の顕微鏡観察による澱粉粒子の状態变化は, Da Silva ら によって報告6) されている化工澱粉の加熱時間の変化によ る膨潤状態の変化と似た結果となった。 即ち, Da Silva ら は, 未処理のワキシーコーンスターチと化工澱粉を $80^{\circ} \mathrm{C}$ で 0.5〜30 分加熱すると, 澱粉粒子表面の㱀が加熱時間に 比例して少なくなり, 粒が膨らんできている現象を観察し ている. Fig. 4 でも同様に澱粉粒子表面の㱀の減少が認め られ，粒が膨潤していることが確認された。このことより， 加熱による澱粉粒子の膨潤と, ずり応力だけによる粒子の 膨潤は同じ現象であると考えた。

加えて,さらに高いずり応力を負荷した（c）の顕微鏡写 真になると, 膨潤した澱粉粒子だけでなく, 小さな粒子屯 見られた。これは，糊化粒子が高ずり応力によって極限ま で膨潤した後, 崩壊したり削れたりした粒子の破片, 即ち, Fig. 3 の粒度分布曲線の $22 \mu \mathrm{m}$ での小さなピークである と推察される.このことから, ある高ずり応力 (WHP-1 で

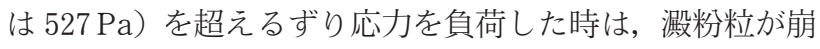
壊することも確認できた。

以上のことから，化工港粉糊化液の流動性およびみかけ 粘度の変化は, 澱粉粒子の膨潤状態を示す澱粉粒子径に依 存していることが示唆された. 以下に, ずり応力を化工澱 粉糊化液に負荷した時に, 糊化液の流動性が増加する現象 を澱粉粒子の状態から説明する.

一般的には澱粉の糊化, 膨潤によって, 糊化澱粉粒子径 は大きくなり, 澱粉粒子外の水 (連続相) よりも粒子内（分 散相）に取り込まれる水の量が多くなることで粒子同士が 密着し, 粒子間のファンデルワールスカが強くなること で，粒子同士のネットワークができて粘度が発現してく る.この糊化液に各ずり応力を負荷すると, 糊化粒子の膨 潤が十分であるほど負荷されたずり応力を連続相だけで吸 収することができずに，膨らんだ粒子が破裂して崩壊して しまう。膨潤澱粉粒子が崩壊すると一度は粒子内に取り込 まれた水が連続相に戻り，膨潤粒子数も減少する。そのた め, 粒子間の密着度も低下し, 粒子同士のネットワークが 弱くなり, 糊化液のみかけ粘度が低下するとともに, 流動 性が増加すると考えた。さらに，高いずり応力を負荷した 時に膨潤粒子が崩壊するかどうかは，粒子の膨潤状態と粒 子密度 (濃度) によって決定されると考えた。これは, Fig. 3 の $320 \mathrm{~Pa}$ を越えたずり応力を負荷した場合での考察で ある. 逆に, $320 \mathrm{~Pa}$ までの負荷ずり応力によって, みかけ 粘度, 糊化粒子径の増加が起こった原因は, 次の流動性が 減少する場合で説明する。

(2) 流動性が減少する場合

ヒステリシスループで上昇曲線が下降曲線を上回る挙動 を示した $4.5 \%(\mathrm{w} / \mathrm{w})$ WHP-2 糊化液に, それぞれ設定し たずり応力を負荷した時のみかけ粘度と糊化澱粉粒子径の 変化を Fig. 5 に示した。

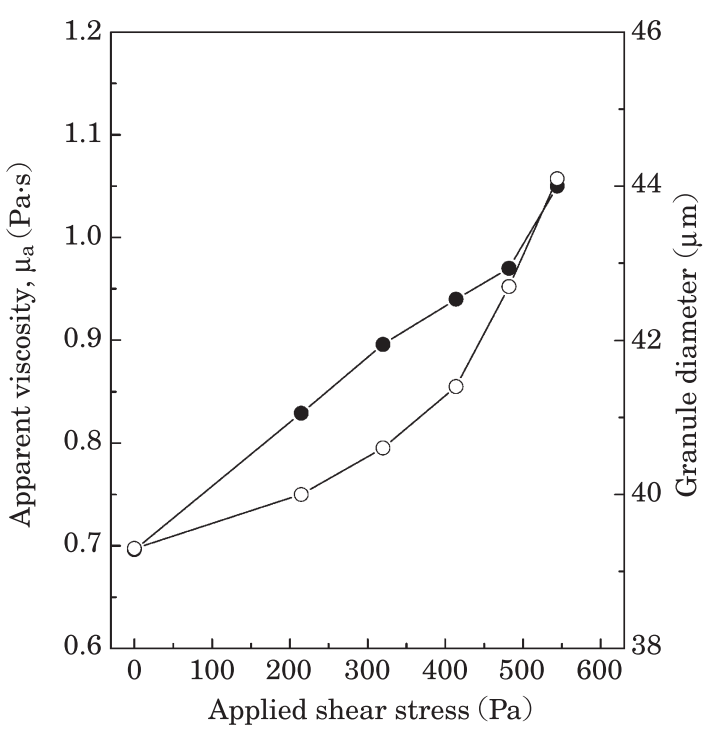

Fig. 5 Influence of applied shear stress on apparent viscosity and granule diameter of $4.5 \%(\mathrm{w} / \mathrm{w})$ WHP-2 suspensions

Measurement temperature $; 20^{\circ} \mathrm{C}$

$\longrightarrow-$ : apparent viscosity

$-\bigcirc-$ : granule diameter

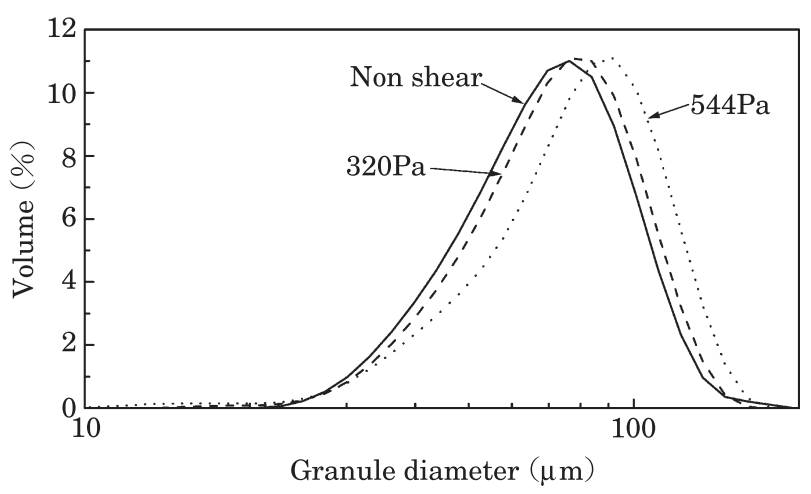

Fig. 6 Influence of applied shear stress on average granule size distribution of gelatinized $4.5 \%$ (w/w) WHP-2 suspensions

Fig. 5 より，負荷ずり応力が増加するに従ってみかけ粘 度は増加し，この時の糊化澱粉粒子径も負荷したずり応力 とともに増大した．この糊化澱粉粒子径の変化を詳細に表 すために，Fig. 6 にその時の粒度分布を，Fig. 7 にその顕 微鏡写真を示した. Fig. 6 では負荷されたずり応力が増加 するに従って粒度分布は大粒径側へ大きくシフトしてお り，糊化澱粉粒子が負荷ずり応力に従って大きくなってい る状態を示した。 また, Fig. 7 でも，個々の糊化澱粉粒子 が大きくなっているのが観察された.

そこで, リン酸架橋度と濃度の異なる $5.0 \%(\mathrm{w} / \mathrm{w})$ WHP-3 糊化液の場合でも，同様に負荷ずり応力の影響を 検討した。 その結果を Fig. 8 に示した. $5.0 \%(\mathrm{w} / \mathrm{w})$ WHP-3 糊化液でも $4.5 \%(\mathrm{w} / \mathrm{w})$ WHP-2 糊化液の場合と 

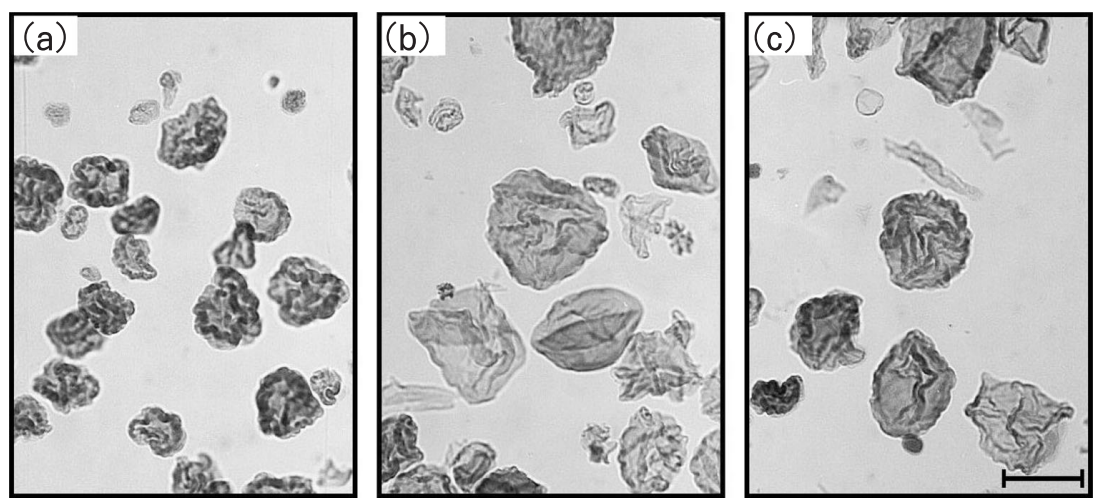

Fig. 7 Photomicrographs of gelatinized $4.5 \%(\mathrm{w} / \mathrm{w})$ WHP-2 granule

(a) : Non shear, (b) : $414 \mathrm{~Pa},(\mathrm{c}): 544 \mathrm{~Pa}, \mathrm{bar}=50 \mu \mathrm{m}$

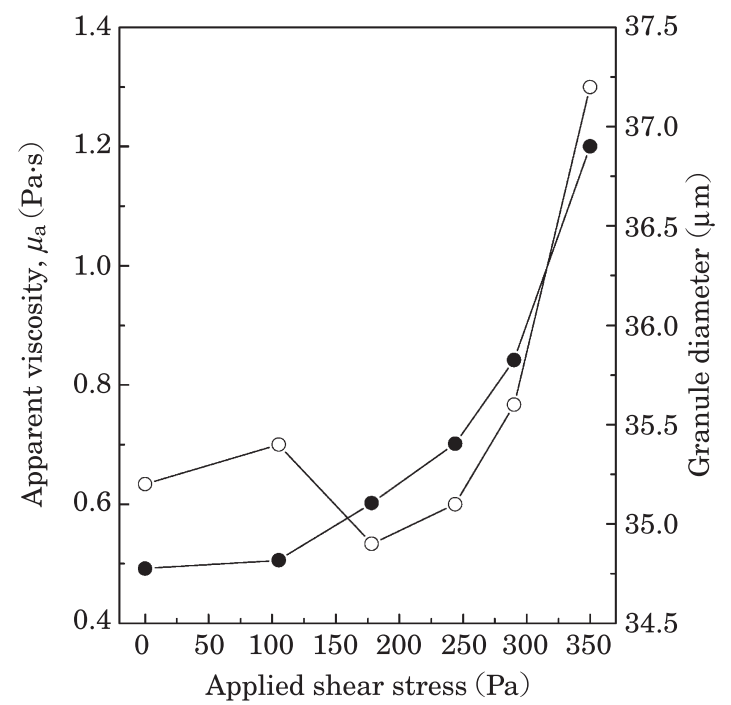

Fig. 8 Influence of applied shear stress on apparent viscosity and granule diameter of $5.0 \%(\mathrm{w} / \mathrm{w})$ WHP-3 suspensions

Measurement temperature ; $20^{\circ} \mathrm{C}$

-- : apparent viscosity

- - : granule diameter

同様に, 負荷ずり応力の増加に従って, みかけ粘度と糊化 澱粉粒子径は増大した。この結果, ずり応力の負荷によっ て流動性が減少する現象（体積流速の低下，みかけ粘度の 増加）は，糊化澱粉粒子径の増大，即ち，糊化澱粉粒子の ずり応力による再膨潤が原因であることが判明した。一度 糊化した澱粉粒子は再加熱されなくとも, 常温でずり応力 が負荷されただけで膨潤する現象を確認した。これら $4.5 \%$ （w/w）WHP-2 糊化液と 5.0\%（w/w）WHP-3 糊化液に, さらに高いずり応力を負荷していくと糊化粒子は膨潤する が， ある高ずり応力からは WHP-1 と同様に糊化粒子は崩 壊した。

この結果から，化工澱粉糊化液にずり応力を負荷した時 に流動性が減少する挙動は, 糊化澱粉粒子がずり応力で再
膨潤することが原因であった．即ち，糊化澱粉粒子が再膨 潤することで粒子径が大きくなり，連続相の水はさらに粒 子内に取り込まれる。こうして膨らんだ各澱粉粒子が稠密 な状態となることで，粒子間のネットワーク形成が容易に なり，粘度がさらに発現すると考えた。.みかけ粘度が増加 することで，糊化液の流動性は低下する．このずり応力負 荷による糊化澱粉粒子径の变化は, 化工澱粉の膨潤度（リ ン酸架橋度に依存する）や糊化液濃度に関与していること が推察された。糊化澱粉粒子がずり応力により崩壊するこ とは，様々な澱粉において報告1213) されているが，逆に， ずり応力によって再膨潤することは本研究において初めて 確認された。

未化工の天然澱粉では, $3.0 \sim 5.0 \%(\mathrm{w} / \mathrm{w})$ 濃度糊化液で は澱粉が充分に加熱・膨潤しているために，ずり応力を負 荷すれば多くの場合が糊化澱粉粒子の崩壊に到るのに対 し，架橋型化工澱粉は，ずり応力抵抗性を持たせるために リン酸などで架橋して，加熱・膨潤を抑制しているため に，ずり応力による再膨潤が起こりえると考えた．また， これは元の加熱糊化液が膨潤不足の場合にも起こると考え られる現象のため，ずり応力（剪断力）に抵抗性を持たな い天然澱粉でも高濃度糊化液になれば膨潤不足を起こし, ずり応力による膨潤が起こりえる可能性がある. 即ち, こ のずり応力負荷による糊化澱粉粒子の再膨潤あるいは崩壊 は, 糊化液濃度や（リン酸）架橋度などの澱粉粒子の膨潤 に影響を与える因子により決定されると推察した。

この化工澱粉糊化液が加熱などの熱エネルギーによら ず, 室温（本研究では $20^{\circ} \mathrm{C}$ ) でのずり応力の負荷だけで糊 化澱粉粒子がさらに膨潤し，流動性が低下することは，実 際のたれ類の生産現場において屯，たれの移送，充填中に かかるずり応力で，たれのレオロジーが変化していること を示唆する，そのため，生産管理としては，たれ類の加熱 条件だけでなくパイプ移送, 容器充填時にたれ類にかかる ずり応力等も把握し, 条件化する必要があることを示し た.さらに，たれ類の品質管理としても，たれの加熱終了 
直後の物性值測定だけでなく, 容器充填後の物性測定も行 わなければならない.

\section{要 約}

化工澱粉糊化液にずり応力を負荷すると, ずり応力に依 存して流動性が増加あるいは減少する流動挙動が確認され た.この原因を化工澱粉の糊化とずり応力負荷に伴う澱粉 粒子の膨潤の面から考察するために, 市販のリン酸架橋度 の異なる化工澱粉を使用し，これらの糊化液の濃度やずり 応力負荷時の流動性, みかけ粘度, 糊化澱粉粒子径, 粒度 分布を測定した。

ずり応力負荷によって糊化液の流動性が増加する挙動 は, 負荷ずり応力によって膨潤澱粉粒子が崩壊して, 糊化 澱粉粒子径が小さくなることで, みかけ粘度が低下するこ とが確認された。この澱粉粒子が負荷ずり応力で崩壊する 現象は, 低リン酸架橋度で高濃度の糊化液で見られた。逆 に, 流動性が減少する挙動は, 負荷ずり応力の増加に伴っ て糊化粒子が再膨潤して粒子径が増大することで, みかけ 粘度が発現して起こった。この流動性減少挙動は, 高リン 酸架橋の高濃度糊化液で認められた。

\section{文献}

1）朝田 仁，鈴木寛一，化工澱粉糊化液の流動特性に与える 港粉濃度, リン酸架橋度及び由来澱粉種の影響, 日食工誌, 39, 929-933 (1992).

2）朝田 仁，鈴木寛一，アセチル化リン酸架橋測粉糊化液の 流動特性に与える澱粉の化学変性程度の影響, 食科工, 51 , 613-619 (2004).

3）朝田 仁，鈴木寛一，化工澱粉糊化液の流動特性のずり応
力依存性，食科工，43，56-63（1996）.

4) Okechukwu, P.E. and Rao, M.A., Influence of granule size on viscosity of cornstarch suspension. J. Texture Stud., 26, 501-516 (1995).

5) Okechukwu, P.E. and Rao, M.A., Role of granule size and size distribution in the viscosity of cowpea starch dispersions heated in excess water. J. Texture Stud., 27, 159-173 (1996).

6) Da Silva, P.M.S., Oliveira, J.C. and Rao, M.A., Granule size distribution and rheological behavior of heated modified waxy and unmodified maize starch dispersions. J. Texture Stud., 28, 123-138 (1997).

7) Ziegler, G.R., Thompson, D.B. and Casasnovas, J., Dynamic measurement of starch granule swelling during gelatinization. Cereal Chem., 70, 247-251 (1993).

8）貝沼圭二, 小田恒郎, 鈴木繁男, 澱粉のリン酸誘導体に関す る研究（第 1 報）無水リン酸による架橋型リン酸澱粉の合 成, 澱粉工業学会誌，14，24-28（1967）.

9) Herschel, W.H. and Bulkley, R., Measurement of consistency of rubber-benzene solutions. Kolloid-Zeitschrift, 39, 291-298 (1926).

10) Suzuki, K., Maeda, T., Matsumoto, K. and Kubota, K., Effects of constituent concentration on rheological properties of corn oil-in-water emulsions. J. Food Sci., 56, 796-798 and 854 (1991).

11）檜作 進，澱粉の糊化と老化，食品工業， 12，（2） 89-98 (1969).

12) Janas, P. and Tomasik, P., Rheological studies on potato starch pastes at low concentrations. Starch, 38, 189-192 (1986).

13) Doublier, J.L., Paton, D. and Llamas, G., A rheological investigation of oat starch pastes. Cereal Chem., 64, 2126 (1987).

(平成 18 年 11 月 1 日受付，平成 19 年 2 月 28 日受理) 